\title{
架橋による広葉樹クラフトパルプシートの 嵩高化
}

VTT フィンランド技術研究センター*1

アンティ・コルペラ，田中篤史*2

\section{Bulky Paper from Chemically Crosslinked Hardwood Kraft} Pulp Fibers

\author{
Antti Korpela and Atsushi Tanaka*2
}

VTT-Technical Research Centre of Finland Ltd. ${ }^{* 1}$

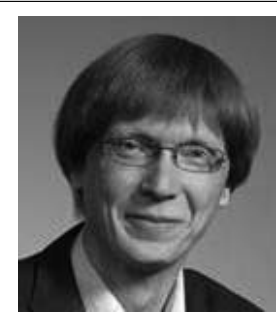

アンティ・コルペラ

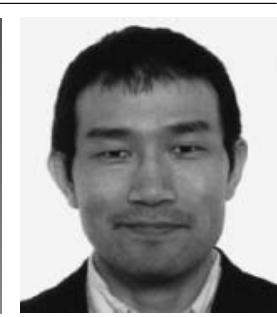

田中篤史

\begin{abstract}
There is a general interest among paper and board makers to produce lighter and bulkier paper and board products. The aim of the present study was to characterize chemically crosslinked hardwood kraft fibers regarding their potential in making bulky paper and board. Crosslinking agents are molecules that contain two or more reactive ends that form inter-chain covalent bonds with cellulosic hydroxyl groups. The formed water resistant crosslinks prevent mutual movement and relocation of cellulosic chains and further, changes in fibers physical shape and dimensions, as the fibers are wetted, mechanically stressed and dried. In paper and board making chemically crosslinked fibers are less prone to swelling and deformation. Blocking of fibers surface hydroxyl groups by reactions with crosslinking agents reduce fibres ability to form inter-fibre hydrogen bonds. In the present study the crosslinking treatments were carried out in laboratory scale. The used pulp was never-dried, bleached hardwood (Betula pendula) kraft pulp. Experiments were performed using various dosages of crosslinking agents followed by beating of the pulp and subsequent standard laboratory paper sheet making. The crosslinking treatments resulted in significantly increased paper sheet bulk. As expected, crosslinking decreased the dry strength of the sheets. However, after moderate refining, crosslinked pulps had much better tensile strength at constant bulk than never-dried or dried reference pulps. An additional advantage of crosslinking treatment is that it improves dewatering ability of the pulp significantly. Thus, use of chemically crosslinked pulp offers an attractive option for manufacture of bulky printing papers and paper boards.
\end{abstract}

Keywords : Bulky paper, Cross-linking, Fiber, Fiber bonding, Pulp beating 分類： $\mathrm{R}_{4}$ クラフトパルプ, $\mathrm{S}_{0}$ その他, $\mathrm{W}_{0}$ その他

\footnotetext{
${ }^{* 1}$ Biologinkuja 7, 02150 Espoo, Finland

${ }^{* 2} \mathrm{E}-$ mail : atsushi.tanaka@vtt.fi

Received : March 19, 2015 Accepted : June 1, 2015

J-STAGE Advance Published : June 8, 2015
}

\section{1. 緒言}

紙・板紙メーカーにとって，製品の軽量化打よび嵩高化 に対する意欲は尽きない。近年，日本の製紙メーカーでは， 瀻維およびウェブに対して, 水素結合を阻害する薬品を用 いて嵩高化する技術が一般的である(12)23415)。一方，ヨーロッ パの板紙メーカーでは，複層ボードの中間層を嵩高化する 

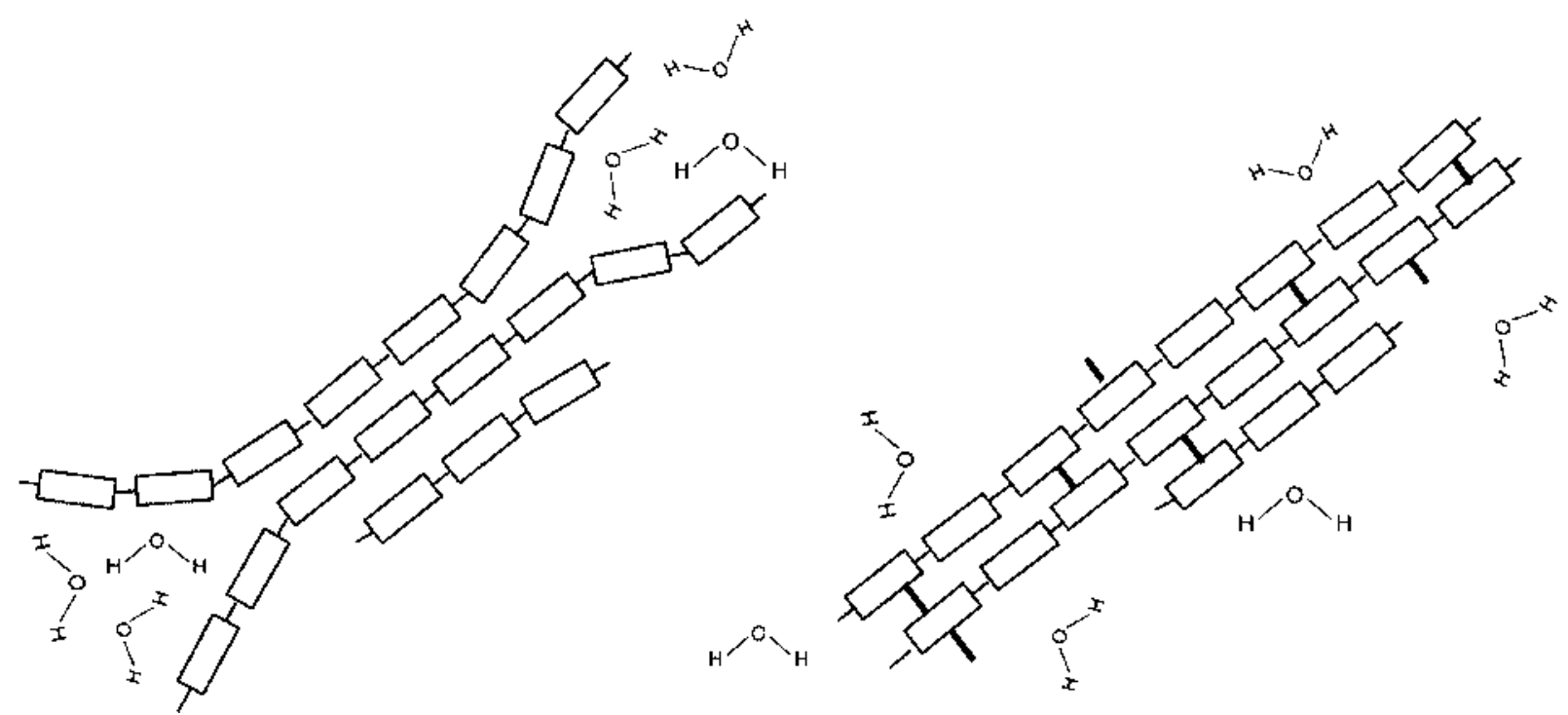

Fig. 1 Cellulosic material prior (left) and after (right) chemical crosslinking treatment. The chemical crosslinks prevent movement and relocation of cellulosic molecules as the material is wetted and mechanically stressed.

ことで，「こし」と軽量化を両立させようとする取り組み が見受けられる。本研究では, 広葉樹クラフトパルプに化 学的な架橋処理を施した場合の製紙性, 特に軽量かつ高白 色度で峪の高い紙・板紙の実現可能性について検討した。

一般的な定義では，七ルロース繊維の架橋とは，繊維の 内部構造を共有結合によって安定化させることを指す。形 成された耐水性のある架橋構造は，セルロース分子鎖の相 互作用や再配置を妨げ，湿潤・応力負荷 ・乾燥といった諸 条件下でも形状やサイズを保持することが出来る(67)8)。図 1 にセルロース材料における架橋の概略を示す。綿織物の分 野では，架橋処理は一般的である。素地を薬液に浸漬した 後, 圧搾, 平滑化, 乾燥, キュアリング処理が施される。 キュアリングは, 温度を上昇させながら行い, この過程で 化学的な架橋反応が起こる。形成された架橋構造により, 洗濯・乾燥を行っても製品の平滑さや形状が保たれる ${ }^{6 / 7) 8)}$ 。 通常, 架橋薬品は, 2 つ以上の反応性末端基を持ち, 七 ルロースの水酸基と共有結合を形成する。セルロースの水 酸基を選択的に対象とする，多く種類の反応性末端基が研 究されてきた ${ }^{9)}$ 。架橋薬品は, 単独で用いられることもあ れば，触媒を併用して，反応速度を上昇させ，必要とされ る温度を下げることもある。今日, 綿・セルロースに対す る架橋剤としては, DMDHEU（1,3-ジメチロール-4, 5ジヒドロキシエチレン尿素）を主体とするものが一般的で ある (図 2 参照)。しかしながら多くの場合, DMDHEU は, 素地に許容基準を超える量のホルムアルデヒドを生成 する問題がある。それゆえ現在では，変性 DMDHEU（m DMDHEU）が開発され，ホルムアルデヒド生成量が抑制 されている。一般的な触媒としては，アンモニウム塩（塩 化アンモニウム，硫酸アンモニウム，硝酸アンモニウム）, 金属塩 (塩化マグネシウム, 硝酸亜鉛, 塩化亜鉛, 硫酸ア ルミニウム, 水酸化塩化アルミニウム), 混合触媒が用い られる(67)899)。ホルムアルデヒドを生成しない方法として, ブタン-1, 2,3,4-テトラカルボン酸 (BTCA）やクエン酸

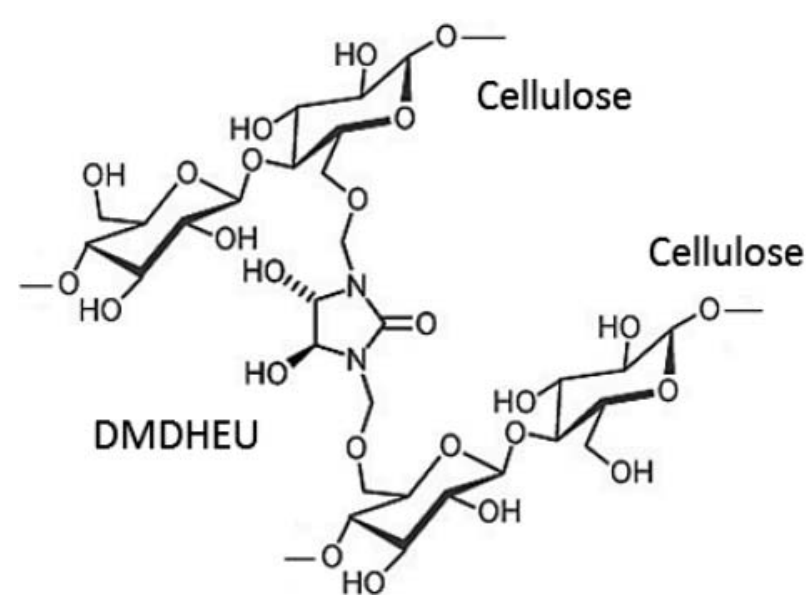

Fig. 2 Crosslinked structure of DMDHEU and cellulose hydroxyl groups.

（CA）のようなポリカルボン酸を用いたエステル架橋も精 力的に研究されている。リン酸のアルカリ金属塩存在下で, BTCA やCA は，セルロースと縮合反応する ${ }^{1011}$ 。

架橋が製紙用パルプ特性に与える影響について記した文 献は非常に少ない。Westervelt と Elstonは, 製紙用パル プ繊維を架橋すると，嵩および空隙率が上昇し，脱水が容 易になると述べている ${ }^{12)}$ 。こういった効果の活用例として は, ろ紙, 吸収材 (毛羽立ちパルプ), ティッシュ・タオ ル等が挙げられる。彼らはまた, 架橋によって繊維間の水 素結合が減少すること, および架橋繊維の吒解で繊維切断 が増加する点を指摘している ${ }^{12)}$ 。なお彼らは, 異なる架橋 薬品の比較や架橋の程度，および架橋条件が繊維の製紙特 性にあたえる影響については論じていない。そこで，本研 究では，広葉樹クラフトパルプに架橋処理を施し，その製 紙特性を調べた。 


\section{2. 試料および実験方法}

\section{1 試 料}

フィンランド国内のパルプ工場から, 未乾燥の広葉樹 (シ ラカンバ, Betula pendula) 晒しクラフトパルプを調達し た。これより, 架橋程度の異なる一連の架橋繊維を準備し た上で，吒解処理を施した。架橋処理については，綿織物 の仕上げに施される一般的な条件にしたがった。浸漬，脱 水 (圧搾), 乾燥, およびキュアリングの各ステージから なる架橋処理後に，パルプ吒解をおこない，手抄きシート を作製した。吒解は，PFI ミルまたはVoith Sulzer LR 1 吒解機にておこなった。Voith 吒解機では，濃度を $4.0 \%$ に調整し，円盤として 2/3-1.46-40 D を用いた。パルプお よびシート特性は，SCAN および ISO 標準に従って測定 した。一方，通常の針葉樹（トウヒ, Picea abies）クラフ トパルプとの配合によるシートも作製した（針葉樹 20\% +広葉樹 $80 \%$ )。なお，この針葉樹クラフトパルプも，フィ ンランド国内のパルプ工場から調達した。

\section{2 架橋処理}

架橋薬品は，BASF 社製 Fixapret AP および Condensol LF（ともにBASF 社製）を混合比 $1 ： 0.37$ にて使用した。 Fixapret AP は，ホルムアルデヒド生成の極めて少ない架 橋剤であり，セルロース系織物の仕上げ処理を容易にする。 Fixapret AP は, 変性ジメチロールジヒドロキシエチレン 尿素 (mDMDHEU) の水溶液である。Condensol LF は, Fixapret AP との併用を推奨される触媒であり, 金属塩と ポリアミドを混合したものである。

ここでは，架橋剤および触媒を $25^{\circ} \mathrm{C}$ のイオン交換水に て希釈した。未乾燥のクラフトパルプをそれに加え，パル プ濃度を $3.33 \%$ に調整した。水酸化ナトリウムと塩酸に て $\mathrm{pH}$ を 6.0 に調整した後，10 分間攪拌して，ブフナー 漏斗（300メッシュ）でろ過し，固形分濃度 $20 \%$ とした。 架橋剂付与量は，ろ液中の残存量から計算した。脱水した パルプケーキは, 解繊後, $110^{\circ} \mathrm{C}$ のオーブンで 2 時間乾燥

し，最後に，140-150ㄷ にて 10 分間キュアリングした。

\section{3 パルプおよびシート特性の測定}

パルプおよびシートの諸特性については，以下の基準に したがって測定した。
Drainability, CSF

ISO 5267-2

Water retention value, WRV SCAN-C 62

Apparent bulk density

EN ISO 5270, ISO 534, EN

ISO 20534

Roughness, Bendtsen

ISO 8791-2, SCAN-P 21

Optical properties of laboratory sheets

ISO 2470, 2471, 9416

ISO brightness ISO 2470

Opacity ISO 2471

Light scattering coefficient ISO 9416

Light absorption coefficient ISO 9416

Tensile properties

EN ISO 5270, EN ISO 1924 $-2$

Tensile index

EN ISO 5270, EN ISO 1924 $-2$

Stretch at break

EN ISO 5270, EN ISO 1924 $-2$

Tensile energy absorption index

Tensile stiffness

EN ISO 1924-2

Elastic modulus

EN ISO 1924-2

Tear index

EN ISO 1924-2

EN ISO 5270, ISO 1974,

EN ISO 21974

Internal bonding strength TAPPI T 569

Resistance to bending, L\&W, $15^{\circ}$

ISO 2493, SCAN P 29

\section{3. 結果と考察}

標準的な離解方法（ISO 5263-1：2004）では，架橋パル プを離解することは出来なかった。このことは，繊維間架 橋による湿潤強度の増加を示唆する。しかしながら， $60^{\circ} \mathrm{C}$ に温度を上げて $0.15 \mathrm{~mm}$ のスロットスクリーン（Valmet 製 TAP 031）を通すことにより，最終的にノットの無い パルプを収率 97-98\% で得ることが出来た。

一連のパルプ・シート特性を表 1 にまとめた。架橋に よって，広葉樹クラフトパルプの嵩が，著しく増加するこ とがわかる (図 3 参照)。なお, 比較対象の標準パルプは, 架橋パルプと同様の乾燥・加熱処理をほどこしたものであ

Table 1 Pulp and sheet properties of the reference pulps and crosslinked birch kraft pulps. Beating was performed using PFI (1,000 rev.). Mixture ratio of Fixapret AP and Condensol LF was $1: 0.37$ respectively.

\begin{tabular}{|l|cc|ccccc|}
\hline & \multicolumn{2}{|c|}{ Ref. (no crosslinking) } & \multicolumn{5}{c|}{ Crosslinked pulp } \\
\cline { 2 - 7 } & wet & $\begin{array}{c}\text { dried \& } \\
\text { heat treated }\end{array}$ & 0.46 & 0.80 & 1.64 & 3.36 & 6.67 \\
\hline CSF, $\mathrm{ml}$ & 500 & 525 & 510 & 520 & 555 & 620 & 660 \\
$\mathrm{WRV}, \mathrm{g} / \mathrm{g}$ & 1.93 & 1.61 & 1.60 & 1.16 & 1.53 & 1.39 & 1.20 \\
Bulk, g/cm & 1.27 & 1.37 & 1.40 & 1.43 & 1.59 & 2.05 & 2.39 \\
Tensile index, Nm/g & 74.7 & 60.8 & 56.1 & 53.6 & 43.9 & 26.1 & 14.5 \\
Tear index, $\mathrm{mNm}^{2} / \mathrm{g}$ & 8.01 & 8.95 & 9.08 & 8.37 & 7.97 & 5.60 & 3.76 \\
Light scattering, $\mathrm{m}^{2} / \mathrm{kg}$ & 22.4 & 26.7 & 27.4 & 27.8 & 29.7 & 32.9 & 37.5 \\
Opacity, \% & 64.4 & 69.0 & 69.9 & 70.0 & 71.5 & 73.7 & 76.2 \\
Brightness, \% & 85.4 & 85.0 & 85.2 & 85.0 & 85.2 & 85.8 & 86.7 \\
\hline
\end{tabular}




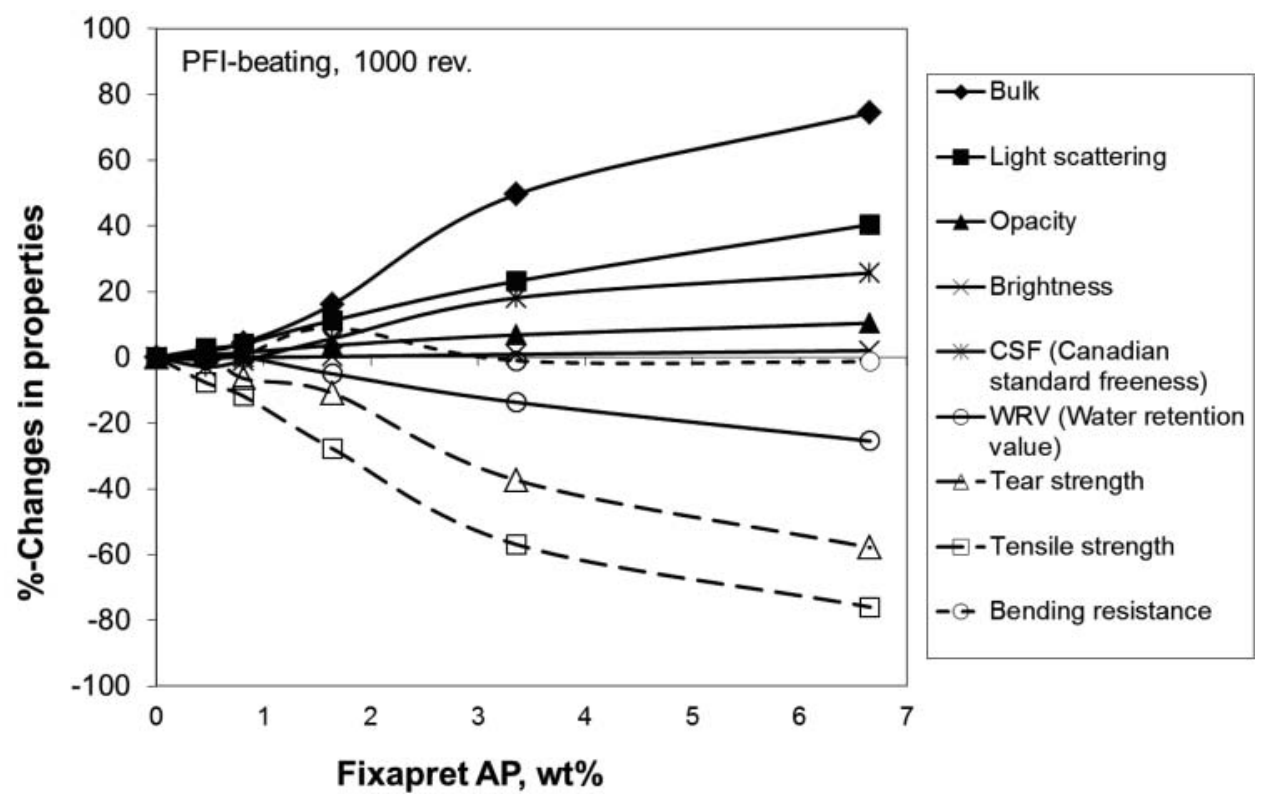

Fig. 3 The effect of chemical crosslinking on the properties of hardwood kraft pulp (Betula pendula). The crosslinking response is almost linear. Mixture ratio of Fixapret AP and Condensol LF was $1: 0.37$ respectively.

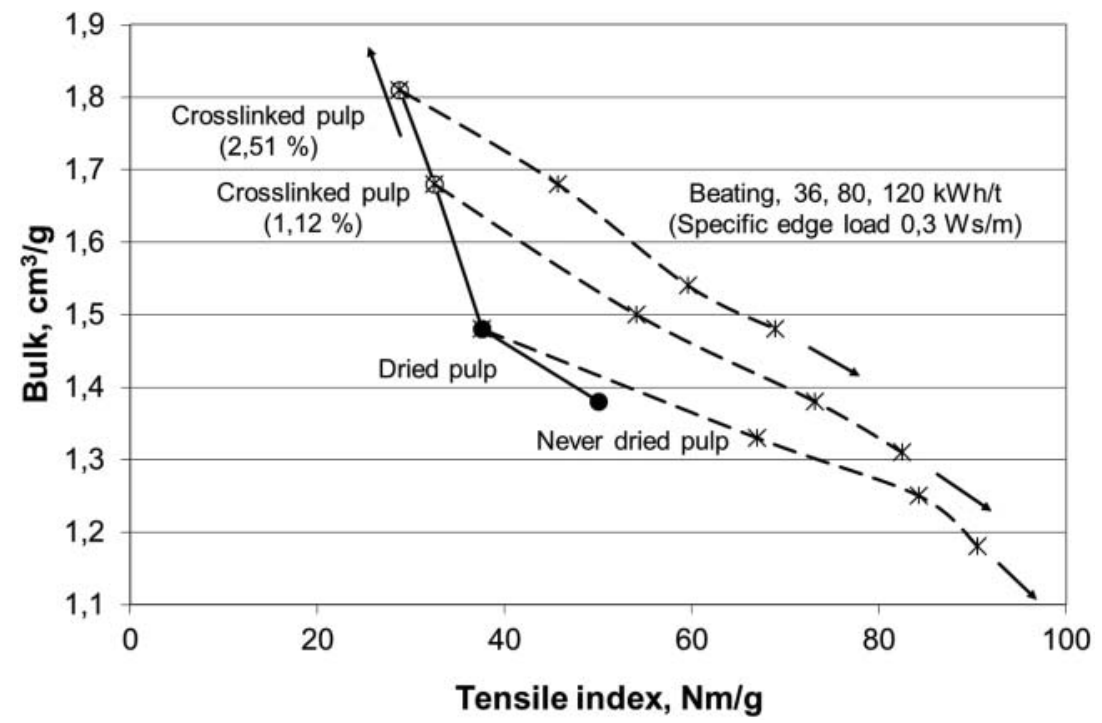

Fig. 4 The effect of drying, chemical crosslinking and beating (Voith Sulzer LR 1 laboratory refiner) on the bulk and tensile strength of hardwood kraft pulp. By crosslinking, it is possible to achieve higher bulk at a constant tensile strength. The dosage (\%) refers to consumption of Fixapret AP. Mixture ratio of Fixapret AP and Condensol LF was $1: 0.58$ respectively. The specific edge load of the beating was $0.3 \mathrm{Ws} / \mathrm{m}$.

る。予想どおり, 架橋繊維では, 乾燥シート強度がかなり 低下した。このように, 架橋は, パルプの乾燥性を上げ, 強度を低下させる。しかしながら, 架橋パルプに適度な吒 解処理を施したところ, 同じ嵪のもとで, 非常に大きな強 度を得られることがわかった（図 4,5 参照）。

架橋処理を施すと，繊維は乾燥し，潰れた様子となる。 また, 形成された架橋ゆえに, 瀻維は水中でも膨潤しなく なる。結果として，保水度（WRV）が低下し，滤水性が 改善される。製紙工程に扔ける脱水性の向上は, 乾燥コス 卜の削減につながり, 同時に生産性の向上が期待される。

一連の配合シートでの結果を表 2 にまとめた。シート作
製において，針葉樹：広葉樹の混合比を一律 $20 ： 80$ とし た。広葉樹パルプを架橋する際の Fixapret AP (架橋剤) および Condensol（触媒）の消費量は，それぞれ $2.42 \%$ ， 1.79\%であった（重量パーセント）。吒解は，Voith 吒解 機でおこなった $(40 \mathrm{kWh} / \mathrm{t}, \mathrm{SEL} 0.5 \mathrm{~J} / \mathrm{m})$ 。広葉樹クラフ トパルプの一部または全部を架橋パルプと置き換えた一連 のシートを準備し，同様にパルプおよびシート特性を測定 した（架橋パルプ混合比 $0 \% ， 20 \% ， 40 \% ， 60 \% ， 80 \%$ )。 混合比がパルプ・シート特性に与える影響を図 6 に示す。 ほとんどの特性は架橋パルプ量に比例した。ただし曲げ強 度は，例外であり，嵩の増加による正の影響と纎維間結合 


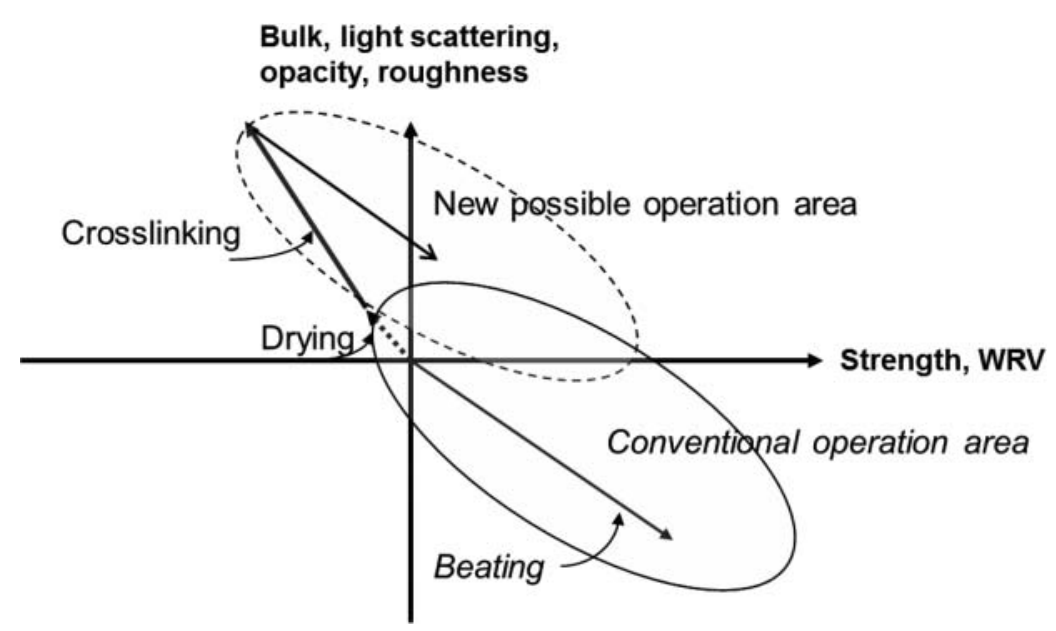

Fig. 5 Chemical crosslinking enables the production of a new type of hardwood kraft pulp for new types of end products.

Table 2 Effect of crosslinked hardwood kraft pulp on the properties of blended sheets. $\mathrm{SW}=$ softwood kraft, HW= hardwood kraft, cHW= crosslinked hardwood kraft pulp (Fixapret AP 2.42\%, Condensol LF 1.79\%)

\begin{tabular}{|c|c|c|c|c|c|c|}
\hline Sample & \#1 & $\# 2$ & $\# 3$ & \#4 & \#5 & \#6 \\
\hline SW, \% & - & 20 & 20 & 20 & 20 & 20 \\
\hline HW feed, \% & - & - & 20 & 40 & 60 & 80 \\
\hline Crosslinked birch kraft pulp, \% & 100 & 80 & 60 & 40 & 20 & - \\
\hline Drainability, CSF, ml & 530 & 495 & 505 & 515 & 525 & 535 \\
\hline Water retention value, WRV, g/g & 1.40 & 1.56 & 1.63 & 1.73 & 1.81 & 1.91 \\
\hline Grammage, $\mathrm{g} / \mathrm{m}^{2}$ & 63.3 & 64.6 & 65.3 & 64.9 & 65.6 & 64.1 \\
\hline Bulking thickness, $\mu \mathrm{m}$ & 121 & 114 & 109 & 101 & 94.1 & 84.9 \\
\hline Apparent bulk-density, kg/m³ & 523 & 565 & 601 & 644 & 697 & 755 \\
\hline Bulk, $\mathrm{cm}^{3} / \mathrm{g}$ & 1.91 & 1.77 & 1.66 & 1.55 & 1.43 & 1.33 \\
\hline Roughness, Bendt, $\mathrm{ml} / \mathrm{min}$, top-side & 1385 & 1301 & 1285 & 1278 & 955 & 782 \\
\hline Roughness, Bendt., ml/min, bottom-s. & 604 & 466 & 418 & 340 & 258 & 142 \\
\hline ISO-brightness, \% & 85.6 & 85.5 & 85.9 & 86.4 & 87.0 & 87.7 \\
\hline Opacity $\left(65 \mathrm{~g} / \mathrm{m}^{2}\right), \%$ & 77.8 & 75.2 & 73.7 & 71.8 & 69.4 & 66.3 \\
\hline Light-scattering coefficient, $\mathrm{m}^{2} / \mathrm{kg}$ & 39.1 & 34.8 & 32.9 & 30.4 & 27.8 & 24.8 \\
\hline Light-absorp. Coeff., $\mathrm{m}^{2} / \mathrm{kg}$ & 0.15 & 0.14 & 0.12 & 0.10 & 0.09 & 0.07 \\
\hline Tensile strength, kN/m & 1.78 & 2.55 & 2.91 & 3.36 & 3.91 & 4.46 \\
\hline Tensile index, Nm/g & 28.2 & 39.5 & 44.6 & 51.8 & 59.6 & 69.7 \\
\hline Stretch, \% & 2.5 & 3.1 & 3.0 & 3.0 & 3.2 & 3.4 \\
\hline Tensile energy absorption, $\mathrm{J} / \mathrm{m}^{2}$ & 33.2 & 57.2 & 63.3 & 73.3 & 88.9 & 107.2 \\
\hline TEA index, $\mathrm{J} / \mathrm{g}$ & 0.524 & 0.886 & 0.97 & 1.13 & 1.36 & 1.67 \\
\hline Tensile stiffness, kN/m & 236 & 297 & 338 & 387 & 436 & 475 \\
\hline Tensile stiffness index, kNm/g & 3.73 & 4.59 & 5.17 & 5.96 & 6.64 & 7.41 \\
\hline Modulus of elasticity, $\mathrm{N} / \mathrm{mm}^{2}$ & 1951 & 2597 & 3108 & 3838 & 4627 & 5595 \\
\hline Tearing strength, $\mathrm{mN}$ & 373 & 559 & 592 & 624 & 597 & 572 \\
\hline Tear index, $\mathrm{mNm}^{2} / \mathrm{g}$ & 5.90 & 8.66 & 9.06 & 9.62 & 9.10 & 8.92 \\
\hline Scott bond strength, $\mathrm{J} / \mathrm{m}^{2}$ & 143 & 188 & 213 & 256 & 321 & 425 \\
\hline Bending resistance $\left(10 \mathrm{~mm}\right.$ length, $\left.15^{\circ}\right), \mathrm{mN}$ & 59.8 & 67.8 & 68.5 & 66.9 & 67.5 & 58.4 \\
\hline
\end{tabular}

の減少による負の影響が相殺する結果となった。また, シー トの引裂き強度は, 繊維長に大きく依存することから, 大 きな違いが見られなかった。

\section{4. 結 言}

架橋（クロスリンク）は, シートに高い嵩, 不透明度お よび脱水性を付与するため, 紙・板紙を製造する上で, 魅
力的な手法と言える。印刷用紙の場合など，低下した強度 や表面粗さを補填するために，紙力増強剤や表面サイズ剤 を必要とするケースも考えられる。もちろんこれは，製品 グレード, 架橋の度合いや紙料中の架橋パルプ混合比にも 依存する。実際の応用例としては，板紙の中間層に適用し て嵪を増加させ, 全体としての曲げ強度も保つといった適 用が挙げられる。一般的に, 嵩高紙に用いられている水素 

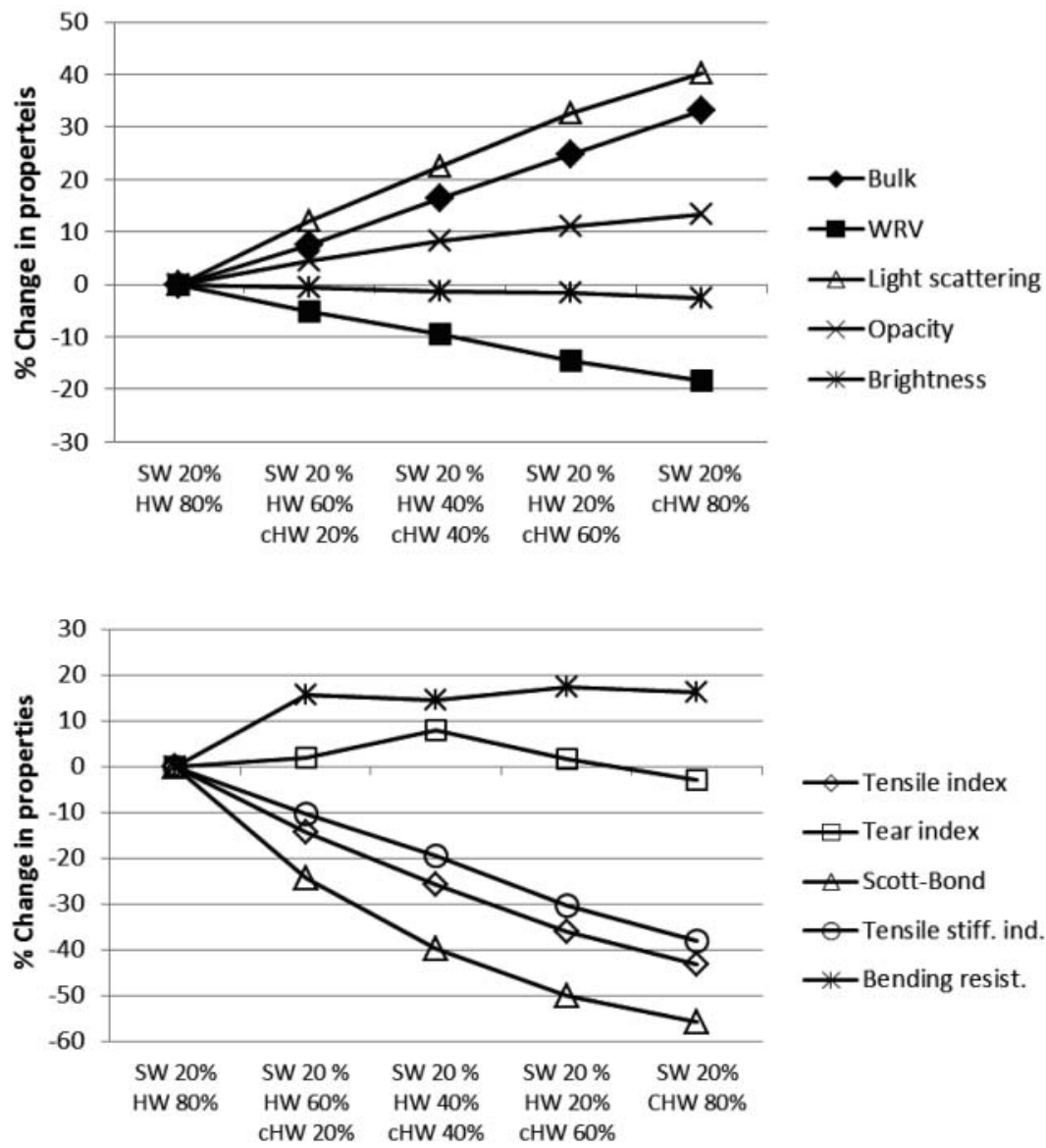

Fig. 6 Effect of crosslinked hardwood kraft pulp on the relative properties of blended sheets. $\mathrm{SW}=$ softwood kraft, $\mathrm{HW}=$ hardwood kraft, $\mathrm{cHW}=$ crosslinked hardwood kraft pulp (Fixapret AP $2.42 \mathrm{wt} \%$, Condensol LF $1.79 \mathrm{wt} \%$ ).

結合を阻害する薬品も，シート強度を低下させ，表面粗さ を増加させるという点では，架橋瀻維と同じ方向性を持つ と言える。

今後さらに研究を進め, 架橋の最適化と, 異なる紙・板 紙製品への適用を検討していきたい。薬品メーカーも含め, 共同研究が出来ればと考えている。

\section{References}

1) Takahashi, H., Tadokoro, T. and Ikeda, $Y$ : Proceedings of The 2000 (67 th) Pulp and Paper Research Conference, JAPAN TAPPI（2000） 42-45

2) Kubota, K., Hiraishi, A., Hamada, Y., Nishimori, T. and Takahashi, H. : JAPAN TAPPI J. 55 (4) 451-455 (2001)

3) Sone, N., Matsushima, T. and Kawamura, M. : JAPAN TAPPI J. 59 (9) 1328-1336（2005）

4) Takishita, M., Otsuka, Y. and Arai, D. : JAPAN TAPPI J. 61 (4) 440-445 (2007)

5) Ochi., T. : JAPAN TAPPI J. 61 (1) 50-53 (2007)

6) Wakelyn, P. J. et al. : Handbook of Fiber Chemistry and technology, 3 rd edition. Edited by Lewin M., CRC Taylor \& Francis (2007) 591-592.

7) Textiles (finishing). Kirk-Othmer Encyclopedia of Chemical Technology, John Wiley \& Sons, 3 rd. edition (1983) vol. 22, 771.

8) Calamari, T. A. and Harper, R. J. : Textiles (finishing). Kirk-Othmer Encyclopedia of Chemical Technology, John Wiley \& Sons, 4 th edition (1997) vol. 23, 890-915.

9) Peter, M. and Rouette, H. K. : Grundlagen der Textil Veredlung. Handbuch der Technologien Verfahren, Machinen. Deutcher Fachverlag GmbH, 13. Auflage (1989) 727-730.

10) Kittinaovarut, S. : Doctoral thesis, Virginia Polytechnic Institute and State University (1998) 175

11) Caulfield, D. F. : Tappi J. 77 (3) 205-212（1994）

12) Westervelt, P. H. and Elston, C. : 1995 Nonwovens conference, TAPPI Proceedings, Atlanta (1995) 6972

(受理：2015.6.1） 